Failures of Feeling 
This page intentionally left blank 


\section{Failures of Feeling}

I N S E N S I B I L I T A N D THE NOVEL

\section{Wendy Anne Lee}

Stanford University Press

Stanford, California 
STANFORD UNIVERSITY PRESS

Stanford, California

(C)2019 by Wendy Anne Lee. All rights reserved.

No part of this book may be reproduced or transmitted in any form or by any means, electronic or mechanical, including photocopying and recording, or in any information storage or retrieval system without the prior written permission of Stanford University Press.

Printed in the United States of America on acid-free, archival-quality paper

Library of Congress Cataloging-in-Publication Data

Names: Lee, Wendy Anne, [date]-author.

Title: Failures of feeling : insensibility and the novel / Wendy Anne Lee.

Description: Stanford, California : Stanford University Press, 2019. | Includes bibliographical references and index.

Identifiers: LCCN 2018009022 | ISBN 978 I 503606807 (cloth : alk. paper) | ISBN 978 I 503607477 (epub)

Subjects: LCSH: English fiction-History and criticism. | Emotions in literature. | Fiction-Psychological aspects.

Classification: LCC PR830.E46 L44 2OI 8 | DDC 823.009/353-DC23

LC record available at https://lccn.loc.gov/20 I 8009022

Typeset by Kevin Barrett Kane in I I/I 4 Adobe Garamond 
For Jong Sook Noh, Colin Christopher Bridge, and Delia Noh Bridge 
This page intentionally left blank 
The uneasiness of being contemned depends on sympathy.

David Hume, A Treatise of Human Nature 
This page intentionally left blank 